\title{
An Investigation of Preservice Teachers' Technological Pedagogical Content Knowledge Based on a Variety of Characteristics
}

\author{
Feride Karaca $^{1}$ \\ ${ }^{1}$ Computer Education and Instructional Technologies, Atatürk Faculty of Education, Marmara University, İstanbul, \\ Turkey \\ Correspondence: Feride Karaca, Computer Education and Instructional Technologies, Atatürk Faculty of Education, \\ Marmara University, İstanbul, Turkey. E-mail: krcferide@gmail.com
}

Received: August 3, 2015

Accepted: September 15, 2015

Online Published: September 21, 2015

doi:10.5430/ijhe.v4n4p128

URL: http://dx.doi.org/10.5430/ijhe.v4n4p128

\begin{abstract}
A survey research was conducted to examine pre-service teachers' Technological Pedagogical Content Knowledge (TPACK) and how it differs based on a variety of characteristics (i.e. gender, grade level, type of high school graduated, possession of different technologies etc.). The participants of the study included 142 preservice teachers from Computer Education and Instructional Technologies Department at Marmara University, Istanbul Turkey. The study results indicated that preservice teachers' TPACK scores differed based on gender, their reasons for choosing their profession, their perceptions of the value of school experience courses and their possession of tablet computers. Understanding the characteristics that would have an influence on preservice teachers' TPACK level provides valuable insights to the development of teacher preparation activities that would lead to more efficient use of technologies in their future professions. As pre-service education has a good potential to influence prospective teachers' use of technologies in their future career, the study results will provide valuable insights about how to improve teachers' technology integration starting from their undergraduate degrees.
\end{abstract}

Keywords: TPACK, Preservice teachers, Technology integration, Teacher education

\section{Introduction}

The challenge for preparing 21st century teachers to use technologies effectively in their courses has led to many different approaches to using technology in teacher education programs. Most teacher education programs have redesigned their curricula to make the preservice teachers competent in using technologies in their future teaching profession (Goktas, Yildirim, Yildirim, 2008). With a curriculum reform of teacher education in Turkey, two different ICT related courses has been added to the teacher education programs in 1998. These courses were "Computer" course, which aimed to improve preservice teachers' competencies about the basic computer applications and "Instructional Technology and Material Development" course aimed to improve preservice teachers' skills in developing and evaluating instructional materials. When provided with necessary ICT education, the pre-service teachers can easily figure out how the technologies might offer a power for enhancing learning and instruction in the real classroom environments. Thus, all these attempts are crucial in preparing prospective teachers to meet the information age learners' needs in their future teaching professions.

In the information age, teachers are expected to be technology leaders and role models for the utilization of technologies in educational environments (Karaca \& Can, Yildirim, 2013b). On the other hand, technology integration is a very complicated process affected by many different factors and conditions (Karaca \& Can, Yildirim, 2013a). In the literature, teacher's technology competencies has been found as one of the most important factors influencing technology integration (Baylor \& Ritchie, 2002; Hew \& Brush 2007; Karaca, Can \& Yildirim,2013a). So, there has been an increasing interest about the definition, dimensions and theoretical foundations of teachers' technology competencies for using technologies.

In the previous studies, there was a tendency to define technology competencies as technical skills and knowledge required to use technologies in the classroom environments. However, the recent research indicated that it is much more than technical skills that teachers feel a need for integrating technologies to their lessons. For effective integration to happen in the classrooms, teachers should have the necessary pedagogical, content and technological competencies at the same time (Abbitt, 2015; Koehler \& Mishra, 2005). To answer this need, a comprehensive model, 
called TPACK, involving all these three competencies has been developed by Koehler and Mishra (2005). Currently, TPACK has been regarded as a valuable framework to provide teachers and academicians new directions to improve teachers' technology integration to classroom settings.

\subsection{Theoretical Background}

The TPACK framework has been built on Shulman (1986)'s Pedagogical Content Knowledge (PCK) to explain effective teaching with technology (Koehler \& Mishra, 2005). At the center of this framework, there are three main areas of knowledge: content, pedagogy and technology. Therefore, TPACK model is composed of "Content Knowledge (TK)", "Pedagogical Knowledge (PK)" and "Technological Knowledge (CK)". First, content knowledge has been defined as teachers' knowledge about subject matter that is intended to be taught. Having proper content knowledge is one of the crucial characteristics of qualified teachers as teachers should have a deep understanding of the fundamentals in their teaching professions (Koehler \& Mishra, 2009). Second, pedagogical knowledge has been defined as teachers' knowledge about "collected practices, processes, strategies, procedures, and methods of teaching and learning" (Koehler \& Mishra, 2005, p.133). This kind of knowledge requires a deep understanding of theories of learning and how they apply to the students in classroom settings. The last type of knowledge is technology knowledge, which has been defined as teachers' knowledge about latest technologies used in the educational environments. Koehler and Mishra explained that the knowledge about technologies is always in a state of change as we are introduced with new technologies every other day. So, having technological knowledge might be more challenging than all others. To answer todays' students' needs, teachers need to follow and learn about latest technologies and utilize them productively in their lessons.

In addition to these three competencies, TPACK model involves combination and intersection these main competencies: "Pedagogical Content Knowledge (PCK)", "Technological Content Knowledge (TCK)", "Technological Pedagogical Knowledge (TPK)" and "Technological Pedagogical Content Knowledge (TPACK)". Koehler and Mishra emphasized that effective technology integration depends on understanding the relationships among these components of knowledge and it requires "continually creating, maintaining and re-establishing dynamic equilibrium among all components" (Koehler \& Mishra, 2009, p.67). Thus, teachers are required to develop competencies not only in each of these three main knowledge domains, but also in the interrelationships of them.

To further understand the relationships among these knowledge domains, several studies have been conducted to investigate the theoretical framework for TPACK. For instance, in a recent study, Kabakci Yurdakul et al. (2012) developed a scale called TPACK-Deep Scale, which is the first scale to specifically investigate Technological Pedagogical Content Knowledge (TPACK) component of the TPACK framework (Kabakci Yurdakull \& Coklar, 2014). Emerging from the interactions of technological, pedagogical and content knowledge, TPACK component is crucial for effective teaching with technology. To further pay attention to the importance of TPACK component, Koehler \& Mishra (2009) explained that:

"TPACK is the basis for effective teaching with technology, requiring an understanding of the representation of concepts using technologies; pedagogical techniques that use technologies in constructive ways to teach content, knowledge of what makes concepts difficult or easy to learn and how technology can help redress some of the problems that students face; knowledge of students' priori knowledge and theories of epistemology; and knowledge of how technologies can be used to build on existing knowledge to develop new epistemologies or strengthen old ones" ( $p$. 66).

Furthermore, Kabakci Yurdakul and Coklar (2014) defined TPACK as "teachers' knowledge of effective and efficient use of technology to increase effectiveness and quality of instruction in the whole teaching process from planning to evaluation in the process of a teaching a specific content." (p.364). However, previous research point to the teachers' low level uses of technologies only for traditional and supplemental activities (Karaca et al., 2013b; O'Dwyer, Russell, and Bebel 2003; Yildirim 2007). Instead of a supplementary teaching tool, technology should be recognized as a requirement to meet the learning goals of todays' students (Karaca et al., 2013b, Ertmer \& Ottenbreit-Leftwich, 2010). Thus, teachers should have the necessary technical and pedagogical skills for improving students' higher order learning skills and cognitive abilities. As pre-service education has a good potential to influence prospective teachers' use of technologies in their future teaching profession, it is important to explore how to improve teachers' technology integration starting from their undergraduate degrees.

In the literature, some studies has been conducted to explore the characteristics that make a difference in pre-service teachers' TPACK level. For example, Abbitt (2014) found that pre-service teachers' Technological Pedagogical Content Knowledge have an influence on their self-efficacy beliefs about technology integration. Moreover, Kabakc1 
Yurdakul (2011) found that teachers' use of a variety of technologies made a difference in their TPACK level. When teachers' use of ICT increased, their level of TPACK was also increased. Similarly, Cakir and Yildirim found that preservice ICT teachers' pedagogical competencies increased throughout their undergraduate education. Actually, pre-service teacher education is the place where the future educators have been prepared for gaining these knowledge and skills. On the other hand, instead of increased access to technologies and training opportunities, low levels of technology usage is also present among preservice teachers (Tondeur, Van Braak, Sang, Fisser, Ottenbreit-Leftwich, 2012). According to Tondeur et al. (2012), this might be because of the inconsistency between what they have been taught in teacher education programs and what happens in real classroom settings. Therefore, teachers should be provided with necessary opportunities to incorporate theory and practice about using technologies during teacher education.

Especially, school experience courses might be very valuable in providing the necessary authentic learning experiences about using technology specifically in their content areas. Incorporating the theory and practice, school experience courses is a vital part of teacher education programs (Merç, 2015). In this courses, the preservice teachers have a chance to improve classroom management skills, to work collaboratively with mentor teachers and learn from them, and also to become familiar with the school environment. On the other hand, Sedumedia and Mundalado (2012) explained that the focus of school experience courses is generally on improving pre-service teachers' classroom management skills other than pedagogical or content knowledge. Therefore, the school experience courses should be redesigned in a way that teachers would have a change to improve their all three kinds of knowledge: pedagogical, content and technology. Currently, TPACK has been regarded as a valuable framework to provide teachers and academicians new directions to redesign and improve the quality of these kinds of courses (Chai, Koh, Tsai \& Tan, 2011).

Several research studies have been conducted to explore how to use TPACK framework to improve pre-service teachers' Technological Pedagogical Content Knowledge. Though there are some studies examining each sub-components of TPACK in the literature, few studies have been conducted to measure the TPACK component. Thus, this study has been conducted to specifically measure pre-service teachers' Technological Pedagogical Content Knowledge. Exploring this knowledge is important since the knowledge and competencies are likely to influence the prospective teachers' success in their future teaching carrier. As pre-service education has a good potential to influence prospective teachers' use of technologies in their future teaching profession, the study results will provide valuable insights about how to improve teachers' technology integration starting from their undergraduate degrees. Furthermore, investigating the future ICT teachers' Technological Pedagogical Content Knowledge is important as effective use of technology in schools highly depends on ICT teachers, who are primarily responsible for integrating technologies into classrooms and assisting other teachers in technology integration process in the schools (Cakir \& Yildirim, 2015).

Moreover, there is a challenge to explore preservice teachers' demographics, competencies, attitudes and beliefs and how these factors affect their future teaching practices when they become professional educators. Thus, the current study has been conducted to examine how pre-service teachers' TPACK scores differ based on a variety of characteristics, involving gender, grade level, the kind of high schools that they have graduated from, their perceptions about the value of school experiences courses, the reasons for choosing their professions and their possession of different technologies. Understanding the characteristics that would have an influence on preservice teachers' TPACK level might provide valuable insights to the development of teacher preparation activities that lead to more efficient use of technologies in their future professions.

\section{Method}

\subsection{Purpose and Research Questions}

The main purpose of this study is to determine pre-service education teachers' TPACK level. Furthermore, this study aimed to examine how pre-service teachers' TPACK scores differ based on the characteristics of gender, grade level, the kind of high schools that they have graduated from, their perceptions about the value of school experiences courses, the reasons for choosing their professions and their possession of different technologies. Three research questions formed the basis of the study:

1. What are the preservice teachers' level of Technological Pedagogical Content Knowledge (TPACK)?

2. Do preservice teachers' TPACK scores vary with respect to gender, grade level, kind of high schools they have graduated from, their reasons for choosing their professions, their perceptions of the value of school experience courses and their possessions of different technologies at home? 
3. Is there a significant relationship between preservice teachers' computer use in years and their TPACK scores?

\subsection{Research Design}

This study utilized a survey research, which involves asking some questions to a group of people about a particular topic or issue (Frankel \& Wallen, 2000).

\subsection{Participants and Sampling}

The sample of the study involved 3rd and 4th grade students at Computer Education and Instructional Technologies Department at Atatürk Faculty of Education in Marmara University. Computer Education and Instructional Technologies is a four-year undergraduate program and this department has students from both I. Schooling and II. Schooling, which gives education following the end of I. Schooling education hours. As Council of Higher Education in Turkey closed II. Schooling in some departments in educational faculties in 2012, II. Schooling students existed in only $4^{\text {th }}$ grade level when the current study took place.

This study utilized convenience sampling method to reach students who are available at the study moment (Frankel $\&$ Wallen, 2000). Some demographic information about the participants has been provided in Table 1. As shown in Table 1, the sample of the study involved 142 undergraduate students, composed of $543^{\text {rd }}$ grade, and $884^{\text {th }}$ grade students. Furthermore, the $4^{\text {th }}$ grade level involved 50 students from I. schooling and 38 students from II. Schooling. The gender distribution was equitable for both male $(n=71)$ and female $(n=71)$ students. Moreover, most participant students were graduated from vocational high school $(67.6 \%)$ and there were no students who graduated from science high school. Finally, as expected, the pre-service teachers from Computer Education and Instructional Technologies department had high computer experiences ranging from 3 to 20 years $(M=10, S D=2.78)$.

Table 1. Characteristics of Sample for the Study ( $\mathrm{N}=142)$

\begin{tabular}{|c|c|c|c|c|}
\hline & $\mathrm{N}$ & & $\mathrm{N}(\%)$ & \\
\hline \multicolumn{5}{|l|}{ Grade Level } \\
\hline 3rd grade & 54 & & 38 & \\
\hline 4 th grade & 88 & & 62 & \\
\hline I. schooling & 50 & & & \\
\hline II. schooling & 38 & & & \\
\hline \multicolumn{5}{|l|}{ Gender } \\
\hline Male & 71 & & 50 & \\
\hline Female & 71 & & 50 & \\
\hline \multicolumn{5}{|l|}{ High school } \\
\hline Vocational High School & 96 & & 67.6 & \\
\hline Public High School & 15 & & 10.6 & \\
\hline Super High School & 6 & & 4.2 & \\
\hline Anatolian High School & 16 & & 11.3 & \\
\hline Science High School & 0 & & 0 & \\
\hline Anatolian Teacher High School & 6 & & 4.2 & \\
\hline \multirow[t]{2}{*}{ Missing } & 3 & & 2.1 & \\
\hline & Minimum & Maximum & $\mathrm{M}$ & SD \\
\hline Age & 19 & 33 & 23 & 2.08 \\
\hline Computer Use in Years & 3 & 20 & 10 & 2.78 \\
\hline
\end{tabular}

\subsection{Instruments}

In this study, the data was collected by a survey, which involved two different parts. The first part of the survey involved some demographic questions, such as age, gender, computer use in years and the type of high schools graduated from. It also involved some questions about pre-service teachers' reasons for choosing this profession, and their perceptions of the value of school experience courses in pre-service education. 
In the second part of the questionnaire, TPACK-Deep scale developed by Kabakci Yurdakul et al. (2012) has been used. This 33 item 5-point Likert-type scale assessed participants' rankings from 1 (strongly disagree) to 5 (strongly agree). In the research conducted by Kabakci Yurdakul et al. (2013), the internal consistency of this scale was found to be very good $(\alpha=.95)$. The same Cronbach's alpha coefficient value $(\alpha=.95)$ was found in the present study, showing high reliability estimates for the scale.

\subsection{Data Analysis}

Data analyses were carried out with descriptive statistics such as frequencies, percentiles, standard deviations and mean values. Furthermore, independent samples t-test, one-way analysis of variance and Pearson correlation tests were conducted to analyze the data.

\section{Results}

\subsection{Pre-service teachers' TPACK level:}

As shown in Table 2, the mean values of pre-service teachers' Technological Pedagogical Content Knowledge was 128, which is accepted as a middle level of TPACK knowledge in the scale (Kabakci Yurdagul et al., 2012). The range of pre-service teachers' TPACK value has been changed from 89 to 165.

Table 2. Pre-service teachers' TPACK scores

\begin{tabular}{lllll}
\hline & $\mathrm{N}$ & $\%$ & $\mathrm{M}$ & $\mathrm{SD}$ \\
\hline TPACK & 142 & 100 & 128 & 16.57 \\
\hline
\end{tabular}

3.2 The relationship between pre-service teachers' computer use in years and their TPACK scores:

A Pearson correlation coefficient was run to determine the relationship between pre-service teachers' computer use in years and TPACK scores. The results indicated no significant correlations between pre-service teachers computer use in years and their TPACK scores $(\mathrm{r}(140)=.082, \mathrm{p}=.341)$.

\subsection{The difference between gender and TPACK scores:}

According to Table 3, there was a significant difference in the scores for males $(\mathrm{M}=125.4, \mathrm{SD}=17.4)$ and females $(\mathrm{M}=132.5, \mathrm{SD}=15.1) ; \mathrm{t}(140)=2.63, \mathrm{p}=0.01$. These results suggest that gender have an effect on preservice teachers' Technological Pedagogical Content Knowledge and female preservice teachers have higher TPACK values than males.

Table 3. The difference between pre-service teachers' gender and TPACK level

\begin{tabular}{lllll}
\hline Gender & $\mathrm{N}$ & $\mathrm{M}$ & $\mathrm{SD}$ & $\mathrm{P}$ \\
\hline Male & 71 & 125.4 & 17.4 & .01 \\
Female & 71 & 132.5 & 15.1 & \\
\hline
\end{tabular}

\subsection{The difference between grade level and TPACK scores:}

According to Table 4, there was no significant difference in the scores for 3th grade $(\mathrm{M}=127.62, \mathrm{SD}=14.77)$ and 4 th grade students $(\mathrm{M}=129.79, \mathrm{SD}=14.77) ; \mathrm{t}(140)=-0.757, \mathrm{p}=0.45$. These results suggest that grade level does not have an effect on preservice teachers' Technological Pedagogical Content Knowledge.

Table 4. The difference between pre-service teachers' grade level and their TPACK scores

\begin{tabular}{lllll}
\hline Grade Level & $\mathrm{N}$ & $\mathrm{M}$ & $\mathrm{SD}$ & $\mathrm{P}$ \\
\hline 3th grade & 54 & 127.62 & 14.77 & .45 \\
4th grade & 88 & 129.79 & 17.62 &
\end{tabular}

\subsection{The difference between the type of high schools graduated and TPACK scores:}

As determined by one-way ANOVA, there was no statistically significant difference between the type of high schools the pre-service teachers graduated from $(\mathrm{F}(4,134)=.796, \mathrm{p}=.53)$. So, the results suggest that the type of high schools that pre-service teachers graduated does not have an influence in their TPACK level.

\subsection{The difference between reasons for choosing their profession and TPACK scores:}

In the questionnaire, the participant students were asked about the reasons for choosing their profession and their answers were provided in Table 5. $47 \%$ of the pre-service teachers have chosen Computer Education and Instructional Technologies department since their university exam scores was sufficient to be able to enter this 
department. Furthermore, many teachers have chosen to be a computer education teacher because of their interests in teaching profession $(\mathrm{N}=44)$ and also their interests in computers and new technologies $(\mathrm{N}=46)$. A small percent of teachers have chosen this profession for job opportunities in both governmental institutions $(9.9 \%)$ and private institutions $(9.2 \%)$. Last, only $2.8 \%$ of teachers have chosen this profession because of their belief in gathering high income from this profession in the future.

Furthermore, this study investigated whether each of the above reasons for choosing this profession make any difference in pre-service teachers' TPACK scores. Among all the reasons, only "my interest in teaching profession" reason made a difference in pre-service teachers" TPACK scores $(\mathrm{t}(140)=.929, \mathrm{p}=0.06)$. In other words, there was a significant difference in the scores of pre-service teachers who have chosen this profession because of their interests in teaching profession $(M=129.8, S D=18.08)$ and who have not $(M=127.4, S D=12.72)$. Thereof, the results indicated that who have chosen this profession because of his interest in being a teacher, have a tendency to have higher TPACK scores.

Table 5. Pre-service teachers' reasons for choosing their profession and their TPACK scores

\begin{tabular}{lll}
\hline & $\mathrm{N}$ & $\%$ \\
\hline $\begin{array}{l}\text { The recommendation from others (i.e. friends, teachers, family } \\
\text { members). }\end{array}$ & 15 & 10.6 \\
$\begin{array}{l}\text { My interest in teaching profession. } \\
\text { My interest in computers and new technologies. }\end{array}$ & 44 & 31 \\
$\begin{array}{l}\text { The chance of finding a job in governmental institutions in the future. } \\
\text { The chance of finding a job in private institutions in the future. }\end{array}$ & 14 & 32.4 \\
$\begin{array}{l}\text { The thought of gathering high income in the future. } \\
\text { Their university entrance exam scores was sufficient to able to enter this } \\
\text { department. }\end{array}$ & 67 & 9.9 \\
\hline
\end{tabular}

\subsection{The difference between perceptions of the value of school experience courses and TPACK scores:}

The pre-service teachers were asked about their perceptions of the value of school experience courses in recognizing and learning about teaching profession. As school experience courses were given in 4th grade in Computer Education and Instructional Technologies Department, only 4th grade students answered this question. Among 4th grade students, $30.7 \%$ of pre-service teachers found school experience courses completely beneficial and $21.6 \%$ of pre-service teachers found it beneficial. On the other hand, 33\% percent of pre-service teachers found school experience courses partially unbeneficial in learning about teaching profession. Furthermore, a small percent of teachers (14.8\%) found school experience courses completely unbeneficial in learning about the teaching profession.

Moreover, there was a statistically significant difference between groups as determined by one-way ANOVA $(\mathrm{F}(3,84)=4.74, \mathrm{p}=.004)$. A Tukey post-hoc test revealed that the TPACK scores for the pre-service teachers who found school experience courses beneficial $(M=138.08 ; \mathrm{SD}=17.3)$ was significantly higher compared to TPACK scores for the pre-service teachers who found school experience courses partially unbeneficial $(\mathrm{M}=121.09$, $\mathrm{SD}=15.72)(\mathrm{p}<.05)$.

\subsection{The difference between having different technologies at home and TPACK scores:}

As shown in Table 6, nearly all pre-service teachers have computers (97.6\%) at their home. Their possession of smart phones are also very high as $90.8 \%$ of them have smart phones. Furthermore, $33 \%$ of teachers have tablet computers at their home. Among all these technologies, only having tablet computers made a difference in TPACK scores. In other words, there was a difference in TPACK scores of students who have tablet computers $(\mathrm{M}=130.36 ; \mathrm{SD}=19.67)$ and who have not $(\mathrm{M}=127.84 ; \mathrm{SD}=15.38) \mathrm{t}(140)=.84, \mathrm{p}=0.04$.

Table 6. Availability of different technologies at home

\begin{tabular}{lll}
\hline & $\mathrm{N}$ & $\%$ \\
\hline Computers & 139 & 97.9 \\
Internet & 113 & 79.6 \\
Tablet & 47 & 33.1 \\
Smart Phone & 129 & 90.8 \\
\hline
\end{tabular}




\section{Discussion}

A survey research was conducted to examine pre-service teachers' Technological Pedagogical Knowledge and how it differed based on a variety of characteristics (i.e. gender, grade level, their possession of different technologies etc.). The results of the study indicated that the preservice teachers had a middle level of Technological Pedagogical Content Knowledge. This result was somehow surprising as the participant teachers were all from Computer Education and Instructional Technologies Department, where a variety of advance courses were provided to improve teachers' technological knowledge. Several researchers explained that teaching ICT skills does not alone lead to effective technology integration, which is only possible when paired with effective teaching (Cetin-Berber \& Erdem, 2015; Chai et al., 2010; Goktas et al., 2008; Mishra et al., 2009). Furthermore, in a recent study, Abbitt (2014) found that attempts to increase technology integration by improving technological skills was not enough to improve teachers' technology-related self-efficacy beliefs.

Actually, it is a common problem in many teacher education programs that necessary attention has not been given to improve pedagogical use of ICT (Chai, Koh \& Tsai, 2010). According to Cakir and Yildirim (2015), teacher training in computer education programs involves courses mostly in special subject matter domain including some technology related courses such as web design, use of operating systems and programming languages. Thus, additional pedagogical courses should be provided to improve pre-service teachers' Technological Pedagogical Content Knowledge. Furthermore, the curriculum should be re-designed in a way that emphasize the interaction and interdependencies of these fundamental knowledge domains. As recommended by several researchers, TPACK framework should be used as a theoretical basis for re-structuring curriculum in teacher education programs (Abbitt, 2014; Chai et al., 2011). ICT should be integrated to entire teacher education programs in a way that results in meaningful technology utilization in prospective teachers' future teaching profession.

In teacher education programs, especially school experience courses might be very valuable in providing the necessary context for improving pre-service teachers' Technological, Pedagogical and Content Knowledge. To understand the benefits of school experience courses from pre-service teachers' views, the present study explored their perceptions of the value of school experience courses in recognizing and learning about teaching profession. Though nearly $31 \%$ of 4 th grade students found school experience courses completely beneficial, $\% 33$ of them found school experience courses partially unbeneficial in learning about teaching profession. According to Cetin-Berber and Erdem (2015), value beliefs has been found one of the best predictors of preservice teachers' intentions to use technologies. Similarly, the current study results indicated that the preservice teachers who believe in the value of school experience courses are likely to have higher TPACK scores. Therefore, some attempts should be taken to improve the quality of school experience courses. As explained by Sedumedia and Mundalado (2012), the focus of school experience courses is generally on improving pre-service teachers' classroom management skills other than pedagogical or content knowledge. Thus, these courses should be redesigned in a way that teachers would have a change to improve their all three kinds of knowledge, pedagogical, content and technology. For example, some practical opportunities might be provided for students to develop technology supported lessons by making connections between all three kinds of knowledge. School experience courses might be very valuable in providing the necessary authentic learning experiences about using technology specifically in their content areas. The pre-service teachers would have a chance to improve a variety of pedagogical, subject matter and teaching skills by observing the mentor teachers and practicing teaching in real classroom environments.

The participant students were also asked about their reasons for choosing their major. According to Strasser, Ozgur and Schroeder (2002), there are three main criteria that students use to select a major in a college: "interest in the subject", "influence of others (advisors, parents, peers)" and "carrier". On the other hand, because of centralized University Entrance Examination in Turkey, the students generally would not have a chance to choose their carrier. Instead, they enter to a department, the score of which matches to their examination scores. The study results supported this idea as the most frequently reason for choosing this profession was that preservice education teachers' university exam scores was sufficient to be able to enter their department. Furthermore, the results showed that several teachers also have chosen to be a computer education teacher because of their interests in teaching profession and also their interests in computers and new technologies. Among all mentioned reasons, only "the interest in teaching profession" reason made a difference in pre-service teachers' TPACK scores. Thus, the study results indicated that the pre-service teachers who have chosen this profession due to their interest in being a teacher, have a tendency to have higher TPACK scores. Similarly, Chai et al. (2013) found a strong relationship between teachers' beliefs about pedagogy and their Technological Pedagogical Content Knowledge. Furthermore, Koksal (2014) found positive relationships between the pre-service teachers' attitudes towards teaching and their general teaching competencies. To further understand this relationship, future studies exploring the relationships between pre-service 
teachers' interests in teaching profession and their Technological Pedagogical Content Knowledge should be conducted.

Finally, the results of the study showed that nearly all pre-service teachers have smart phones and computers at their home. Also, 79\% of teachers have Internet and 33\% of teachers have tablet computers. Among all these technologies, only having tablet computers made a difference in pre-service teachers' TPACK scores. Similarly, Kabakc1 Yurdakul (2011) found that pre-service teachers' use of a variety of technologies made a difference in their TPACK level. Thus, some teaching and learning experiences with ICTs, especially with tablet computers should be provided in teacher education programs. Before going into their future teaching profession, the preservice teachers should have a chance to develop some sample lessons, in which pedagogical, content and technological knowledge used together in any instructional processes. Furthermore, if having tablet computers is likely to make a difference in teachers' TPACK scores, it would be a good idea to provide some opportunities for university students to have tablet computers. To do this, the Universities might make some arrangements with private corporations to provide tablet computers for university students at lower costs.

Recently, Turkish Ministry of National Education developed a large-scale technology integration project called FATIH (Increasing Opportunities and Improvement of Technology Movement) to provide Tablet computers for public schools. However, the teachers encountered some pedagogical problems in using these tablet PCs such as teachers' lack of knowledge to use these technologies, their limited understanding of how to use technologies in teaching and their difficulties in managing technology supported lessons (Pamuk, Cakir, Ergun, Yilmaz \& Ayas, 2013). According to Koehler and Mishra (2009), teaching with technology is an ill structured domain, which requires a deep understanding in all three knowledge types and interactions among them. Having the necessary TPACK knowledge provides the teachers with required pedagogical techniques to teach content in creative ways, to deal with problems encountered during the instruction, to use technology effectively and to creatively design the courses for particular subjects in different classroom contexts (Koehler \& Mishra, 2009). For this reason, teachers should also be provided with necessary in-service training opportunities to improve their Technologial Pedagogical Content Knowledge. As pre-service education has a good potential to influence prospective teachers' use of technologies in their future teaching profession, the study results will provide valuable insights about how to improve teachers' technology integration starting from their undergraduate degrees. Further studies should be conducted to explore the ways to improve teachers' TPACK in real classroom environments.

Examining the pre-service teachers' TPACK scores based on a variety of characteristics, the current study results provided valuable insights to the development of teacher preparation activities that would lead to more efficient use of technologies in their future professions. This study paid attention to the idea that ICT related knowledge should be accompanied wih the necessary pedagogical and subject matter knowledge to lead to effective technology integration in educational settings. In this regard, TPACK has been regarded as a valuable framework to provide teachers and academicians new directions to integrate technologies to the lessons. Utilizing survey research, the generalizability of the current study depends on the honesty of the participants. To improve the generalizability of the results, further studies involving some qualitative methods of data collection should be conducted with pre-service teachers from different departments in teacher education programs.

\section{References}

Abbitt, J. T. (2011). An investigation of the relationship between self-efficacy beliefs about technology integration and technological pedagogical content knowledge (TPACK) among preservice teachers. Journal of Digital Learning in Teacher Education, 27(4), 134-143. http://dx.doi.org/10.1080/21532974.2011.10784670

Baylor, A. L., and D. Ritchie. (2002) "What Factors Facilitate Teacher Skill, Teacher Morale, and Perceived Student Learning in Technology-using Classrooms?" Computers and Education, 39 (4): 395-414. http://dx.doi.org/10.1016/S0360-1315(02)00075-1

Cakir, R., \& Yildirim, S. (2015). Who are They Really? A Review of the Characteristics of Pre-service ICT Teachers in Turkey. The Asia-Pacific Education Researcher, 24(1), 67-80. http://dx.doi.org/10.1007/s40299-013-0159-9

Cetin-Berber, D., \& Erdem, A. R. (2015). An Investigation of Turkish Pre-Service Teachers' Technological, Pedagogical and Content Knowledge. Computers, 4(3), 234-250.http://dx.doi.org/10.3390/computers4030234

Chai, C. S., Koh, J. H. L., \& Tsai, C. C. (2010). Facilitating preservice teachers' development of technological, pedagogical, and content knowledge (TPACK). Journal of Educational Technology \& Society, 13(4), 63-73.

Chai, C. S., Koh, J. H. L., Tsai, C. C., \& Tan, L. L. W. (2011). Modeling primary school pre-service teachers' Technological Pedagogical Content Knowledge (TPACK) for meaningful learning with information and 
communication technology (ICT). Computers \& Education, 57(1), 1184-1193. http://dx.doi.org/10.1016/j.compedu.2011.01.007

Ertmer, P. A., and A. T. Ottenbreit-Leftwich. (2010) Teacher Technology Change: How Knowledge, Confidence, Beliefs, and Culture Intersect. Journal of Research on Technology in Education, 42 (3): 255-284. http://dx.doi.org/10.1080/15391523.2010.10782551

Frankel, J., \& Wallen, N. (2000). How to design and evaluate research in education. Boston, MA: McGraw-Hill Higher Education.

Goktas, Y., Yildirim, Z., \& Yildirim, S. (2008). A review of ICT related courses in pre-service teacher education programs. Asia Pacific Education Review, 9(2), 168-179. http://dx.doi.org/10.1007/BF03026497

Hew, K. F., and T. Brush. (2007) "Integrating Technology into K-12 Teaching and Learning: Current Knowledge Gaps and Recommendations for Future Research." Educational Technology Research and Development, 55 (3): 223-252. http://dx.doi.org/10.1007/s11423-006-9022-5

Kabakci Yurdakul, I. (2011). Examining technopedagogical knowledge competencies of preservice teachers based on ICT usage. Hacettepe University Journal of Education, 40, 397-408.

Kabakci Yurdakul, I., Odabasi, H.F., Kilicer, K, Coklar, A.N., Birinci, G., Kurt, A.A. (2012). The development, validity and reliability of TPACK-deep: A technological pedagogical content knowledge scale. Computers \& Education, 58 (3), 964-977. http://dx.doi.org/10.1016/j.compedu.2011.10.012

Kabakci Yurdakul, I., \& Coklar, A. N. (2014). Modeling preservice teachers' TPACK competencies based on ICT usage. Journal of Computer Assisted Learning, 30(4), 363-376. http://dx.doi.org/10.1111/jcal.12049

Karaca, F., Can, G., \& Yildirim, S. (2013a). A path model for technology integration into elementary school settings in Turkey. Computers \& Education, 68, 353-365. http://dx.doi.org/10.1016/j.compedu.2013.05.017

Karaca, F., Can, G., \& Yildirim, S. (2013b). Technology utilisation in elementary schools in Turkey's capital: a case study. Educational Studies, 39(5), 552-567. http://dx.doi.org/10.1080/03055698.2013.807726

Koehler, M. J., \& Mishra, P. (2005). What happens when teachers design educational technology? The development of technological pedagogical content knowledge. Journal of educational computing research, 32(2), 131-152. http://dx.doi.org/10.2190/0EW7-01WB-BKHL-QDYV

Koehler, M., \& Mishra, P. (2009). What is technological pedagogical content knowledge (TPACK)?. Contemporary issues in technology and teacher education, 9(1), 60-70.

Merç, A. (2015). Assessing the Performance in EFL Teaching Practicum: Student Teachers' Views. International Journal of Higher Education, 4 (2), 44-56. http://dx.doi.org/10.5430/ijhe.v4n2p44

O'Dwyer, L., Russell, M., \& Bebel, D. (2004). Elementary teachers' use of technology: Characteristics of teachers, schools, and districts associated with technology use. Boston, MA: Technology and Assessment Study Collaborative, Boston College.

Strasser, S. E., Ozgur, C., \& Schroeder, D. L. (2002). Selecting a business college major: An analysis of criteria and choice using the analytical hierarchy process. American Journal of Business, 17(2), 47-56. http://dx.doi.org/10.1108/19355181200200010

Pamuk, S., Çakır, R., Ergun, M., Yılmaz, H. B., \& Ayas, C. (2013). The use of tablet PC and interactive board from the perspectives of teachers and students: Evaluation of the FATIH Project. Educational Sciences: Theory \& Practice, 13 (3), 1815-1822.

Sedumedi, T. D. T., \& Mundalamo, F. J. (2012). Understanding field assessment of pre-service teachers on school practicum. Africa Education Review, 9(1), S73-S90. http://dx.doi.org/10.1080/18146627.2012.755247

Yildirim, S. (2000). Effects of an educational computing course on preservice and inservice teachers: A discussion and analysis of attitudes and use. Journal of Research on computing in Education, 32(4), 479-495. http://dx.doi.org/10.1080/08886504.2000.10782293

Yildirim, S. (2007). Current Utilization of ICT in Turkish Basic Education Schools: A Review of Teacher's ICT Use and Barriers to Integration. International Journal of Instructional Media, 34 (2): 171-186. 